\title{
PENGARUH TATA RUANG PADA PENGHAWAAN ALAMI RUMAH VERNAKULAR MELAYU PONTIANAK
}

\section{Tri Wibowo Caesariadi}

Jurusan Arsitektur, Fakultas Teknik, Universitas Tanjungpura

tricaesariadi@teknik.untan.ac.id

\begin{abstract}
Abstrak
Arsitektur vernakular adalah arsitektur yang memiliki respon yang baik terhadap iklim setempat. Hal ini juga berpengaruh terhadap kenyamanan termal dalam bangunan. Sebagai kota yang memiliki iklim tropis lembab, kenyamanan termal bangunan di Kota Pontianak banyak ditentukan oleh pergerakan angin yang terjadi di dalam bangunan. Adaptasi terhadap iklim pada rumah vernakular melayu Pontianak tidak hanya pada penggunaan elemen bangunan seperti bukaan dan bahan bangunan, juga pada tata ruang yang khas, di antaranya terdapat teras, ruang tengah serta pelataran belakang yang memisahkan rumah induk dengan rumah anak. Tujuan penelitian adalah melihat apakah tata ruang ini berpengaruh terhadap penghawaan alami di ruang dalam. Penelitian dilakukan dengan pengukuran di lapangan terhadap variabel kenyamanan termal, terutama temperatur dan kelajuan angin. Kemudian hasil pengukuran dianalisis secara deskriptif kuantitatif dan dilihat hubungan antara variabel dengan tata ruang, yaitu bagaimana temperatur dan kelajuan angin yang berbeda terjadi di setiap ruang, sehingga dapat ditarik kesimpulan. Hasil penelitian menunjukkan bahwa tata ruang di rumah vernakular melayu Pontianak, yaitu hadirnya teras dan pelataran belakang turut berperan dalam penghawaan alami yang terjadi di ruang dalam. Teras berperan dalam menurunkan temperatur luar yang masuk ke dalam bangunan $\left(30,74{ }^{\circ} \mathrm{C}\right.$ di ruang luar, lalu $29,84{ }^{\circ} \mathrm{C}$ di teras depan, dan $29,09{ }^{\circ} \mathrm{C}$ di ruang dalam). Pelataran belakang serta tata ruang dalam memberikan pergerakan angin yang lebih baik, ditunjukkan dengan selisih yang kecil antara kelajuan angin di ruang dalam dengan ruang luar pada rumah dengan pelataran belakang $(0,51 \mathrm{~m} / \mathrm{s})$ dibandingkan dengan rumah tanpa pelataran belakang $(0,77 \mathrm{~m} / \mathrm{s})$.
\end{abstract}

Kata-kata Kunci: penghawaan alami, vernakular, tata ruang

\section{EFFECT OF SPACE LAYOUT TO NATURAL VENTILATION IN MELAYU PONTIANAK VERNACULAR HOUSE}

\begin{abstract}
Vernacular architecture is architecture that has good response to local climate. This also affects the thermal comfort in the building. As a city that has a humid tropical climate, the thermal comfort of buildings in Kota Pontianak is largely determined by the movement of the wind that occurs inside the building. Adaptation to climate in Pontianak's melayu vernacular house is not only on the use of building elements such as openings and building materials, but also on the typical spatial layout, including a terrace, a central room and a back veranda that separates the main house from the secondary house. The aim of the study was to see whether this spatial arrangement has an effect on natural ventilation in the indoor space. The study was conducted with measurements of thermal comfort variables, especially temperature and wind speed. Then the measurement results were analyzed descriptively quantitatively and viewed the relationship between variables and spatial
\end{abstract}


arrangement - i.e. how the temperatures and wind speed differ in each rooms - so that conclusions could be drawn. The results showed that the layout in Pontianak's melayu vernacular house, namely the presence of terraces and back veranda, played a role in the natural ventilation that occurred in the indoor space. The terrace plays a role in reducing the outside temperature that enters the building $\left(30.74{ }^{\circ} \mathrm{C}\right.$ in the outdoor, then $29.84{ }^{\circ} \mathrm{C}$ on the front terrace, and $29.09{ }^{\circ} \mathrm{C}$ in the indoor). Back veranda and spatial layout provide better wind movement, indicated by small difference between the speed of wind in the indoor and the outdoor space of the house with back veranda $(0.51$ $\mathrm{m} / \mathrm{s}$ ) compared to the house without back veranda $(0.77 \mathrm{~m} / \mathrm{s})$.

Keywords: natural ventilation, vernacular, spatial layout

\section{Pendahuluan}

Arsitektur yang berkembang secara turun temurun dari generasi ke generasi di suatu tempat tertentu, yang sering kali disebut sebagai arsitektur vernakular, umumnya adalah arsitektur yang memilik respon yang baik terhadap iklim setempat. Arsitektur vernakular berkembang seiring dengan kebutuhan sosial dan fisik masyarakatnya. Proses trial and error yang telah dilakukan selama turun temurun mampu mencapai kondisi penyesuaian yang dinamis terhadap lingkungannya. Dengan demikian arsitektur vernakular dapat dilihat sebagai solusi yang sangat efektif bagi kebutuhan penghuninya secara fisik akibat tuntutan keadaan lingkungan (Gutierrez, 2004).

Salah satu ciri arsitektur vernakular adalah tanggap dengan iklim dengan memberikan kenyamanan bagi penghuninya melalui cara pasif, salah satunya dengan menyediakan lingkungan termal yang baik. Kondisi lingkungan termal tersebut dapat diusahakan di antaranya melalui pengaturan tata ruang yang khas. Engin dkk (2005) menemukan bahwa rumah vernakular di wilayah timur Laut Hitam, Turki, memiliki pengaturan denah yang ternyata merupakan hasil tanggapan terhadap iklim setempat untuk menciptakan lingkungan termal yang lebih nyaman. Penelitian lain pada rumah vernakular di Dibaryakir, Turki, oleh Sozen dan Gedik (2006) menyimpulkan bahwa adanya taman dalam (inner court) juga merupakan hasil pengaturan tata ruang yang tanggap dengan iklim.

Arsitektur vernakular masyarakat melayu kota Pontianak juga memiliki tata ruang yang khas dan tidak ditemui pada rumah melayu lain di Indonesia. Tata ruang rumah vernakular masyarakat melayu Pontianak terbagi menjadi teras di bagian depan, ruang tamu, kemudian ruang tengah yang biasanya dibagi-bagi dan berfungsi sebagai kamar tidur, ruang terbuka atau pelataran, dan dapur di bagian belakang. Bentuk tipikal rumah vernakular melayu Pontianak dapat dilihat pada Gambar 1 .

Tata ruang yang khas pada rumah ini adalah adanya ruang tengah dan ruang terbuka atau pelataran belakang. Ruang tengah biasanya terletak di tengah bangunan diapit oleh deretan ruang tidur di kiri dan kanannya. Pelataran belakang merupakan ruang terbuka yang memisahkan bangunan induk (ruang tamu, ruang tidur) dengan dapur. Pelataran ini umumnya tanpa atap namun diberi dinding samping setinggi sampai dengan $2 \mathrm{~m}$. Kedua ruang ini dapat dilihat sebagai ruang berbentuk lorong di bangunan ini.

Pontianak adalah salah satu kota di pulau Kalimantan, Indonesia. Pontianak merupakan kota yang terletak tepat di garis khatulistiwa pada dataran yang relatif rendah, sehingga memiliki ciri iklim tropis basah, yaitu rata-rata temperatur tinggi (maksimum $32,35^{\circ} \mathrm{C}$ ), kelembaban udara tinggi (rata-rata 86,15\%), dengan kelajuan udara rendah (rata-rata 2,64 m/s pada ketinggian $10 \mathrm{~m}$ ). Kondisi termal di Pontianak umumnya dirasakan panas dan tidak nyaman. Cara utama untuk menyikapi kondisi termal di iklim panas lembab seperti Pontianak adalah dengan mengusahakan pergerakan udara yang maksimal (Koenigsberger dkk, 1973; Szokolay, 2008; Lechner, 2001). Pergerakan dan pergantian udara yang baik akan menyebabkan panas dan lembab tinggi yang terdapat dalam bangunan dibawa keluar dan digantikan oleh udara yang lebih segar. 


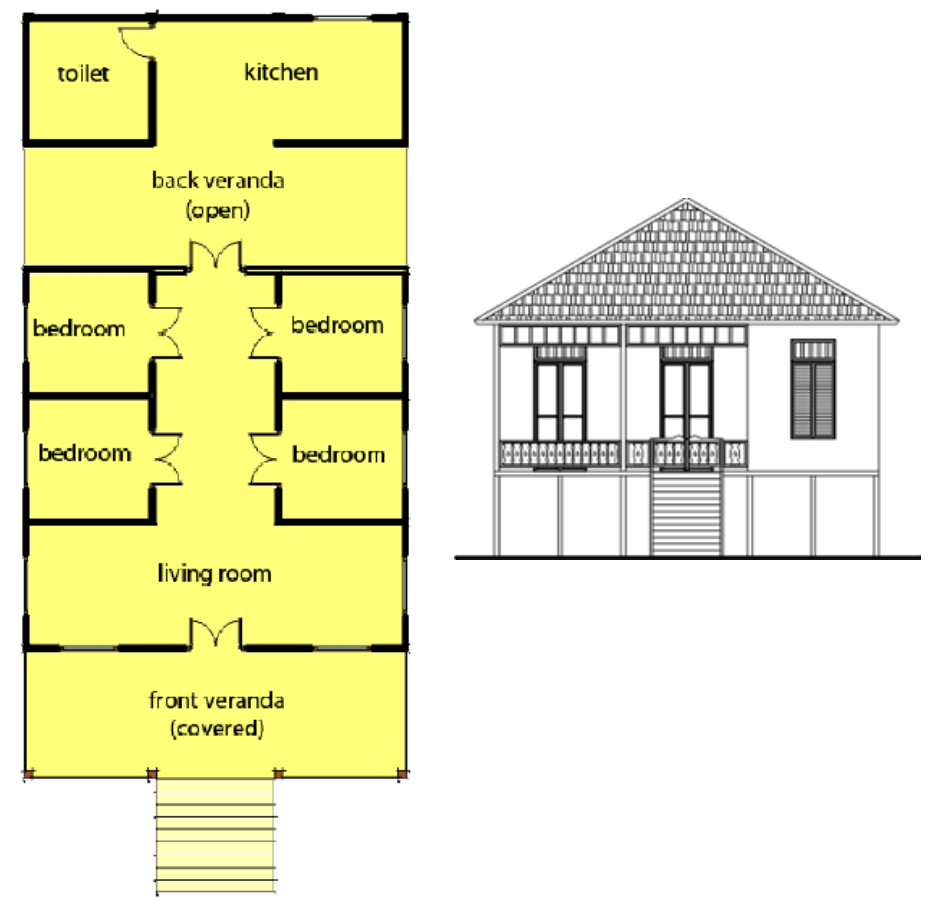

Gambar 1. Tipikal rumah vernakular melayu Pontianak Sumber: Caesariadi \& Kalsum, 2011

Dengan melihat tata ruang rumah vernakular melayu Pontianak yang khas, yaitu adanya ruang tengah dan pelataran belakang, serta pergerakan udara sebagai cara utama menyikapi kondisi termal, maka diprediksi bahwa ruang tengah dan pelataran ini dihadirkan untuk mendukung kenyamanan termal dalam bangunan dengan memaksimalkan pergerakan udara yang terjadi. Hal ini menarik untuk diteliti, salah satunya melihat bagaimana fenomena pergerakan udara yang terjadi di lapangan. Sehingga tujuan dari kajian ini adalah melihat apakah hadirnya ruang tengah dan pelataran belakang memberikan pengaruh terhadap pergerakan udara sebagai faktor utama kinerja penghawaan alami di rumah vernakular melayu Pontianak.

\section{Kerangka Teoritis Iklim Tropis Basah}

Daerah tropis (dari bahasa Yunani: tropikos, garis balik) adalah daerah di bumi yang terletak di antara dua garis balik yaitu garis balik Cancer (garis $23^{\circ} 27^{\prime} \mathrm{LU}$ ) dan garis balik Capricorn (garis $23^{\circ} 27^{\prime}$ LS). Namun saat ini daerah tropis lebih dilihat sebagai daerah yang terletak di antara bagian yang mempunyai temperatur rata-rata tahunan tidak lebih dari $20^{\circ} \mathrm{C}$ (Lippsmeier, 1997; Koenigsberger dkk, 1973).

Wilayah Indonesia yang terletak di antara $5^{\circ} 39^{\prime}$ LU dan $10^{\circ} 22^{\prime}$ LS masuk di dalam zona iklim tropis basah. Cuaca di iklim ini relatif sama sepanjang tahun tanpa banyak variasi, yang membedakan adalah adanya waktu-waktu curah hujan lebih tinggi dan terjadinya angin ribut dan badai. Ciri lain iklim tropis basah yang berkaitan dengan penelitian ini adalah (Koenigsberger dkk, 1973; Lippsmeier, 1997):

- Temperatur udara siang hari adalah $27^{\circ}-32^{\circ} \mathrm{C}$, terkadang melebihi $32^{\circ} \mathrm{C}$; temperatur malam hari $21^{\circ}-27^{\circ} \mathrm{C}$. Fluktuasi temperatur rata-rata relatif kecil, baik harian $\left(5,5^{\circ}-8,5^{\circ} \mathrm{C}\right)$ maupun tahunan $\left(3-5,5^{\circ} \mathrm{C}\right)$.

- Kelembaban udara tinggi, rata-rata 75\% namun dapat bervariasi dari 55\% sampai $100 \%$.

- Kelajuan angin umumnya rendah, namun angin kuat dapat terjadi saat hujan badai. Biasanya terdapat satu atau dua arah angin utama. 


\section{Kenyamanan Termal}

Kondisi nyaman secara termal merupakan salah satu dasar kebutuhan fisik/biologis manusia (Maslow, 1984 dalam Szokolay, 2008). Proses metabolisme yang terjadi dalam tubuh manusia mengeluarkan panas yang harus dilepaskan dari tubuh agar temperatur tubuh tetap terjaga.

Temperatur udara merupakan faktor paling dominan yang menentukan pelepasan panas tubuh secara konvektif. Pergerakan udara dapat mempercepat proses konveksi sekaligus proses penguapan dari kulit dan menghasilkan efek pendinginan. Kecepatan angin sampai dengan $0,5 \mathrm{~m} / \mathrm{s}$ masih dirasakan nyaman, sampai dengan $1 \mathrm{~m} / \mathrm{s}$ dirasakan namun siaga, sementara di atas kecepatan tersebut sudah dirasakan tidak nyaman. Namun pada kondisi sangat panas, kecepatan udara sampai dengan 2 $\mathrm{m} / \mathrm{s}$ masih dapat diterima (Szokolay, 2008).

Tabel 1. Reaksi Subyektif terhadap Pergerakan Udara

\begin{tabular}{cc}
\hline Kecepatan Angin $(\mathbf{m} / \mathbf{s})$ & Reaksi \\
\hline$<0,1$ & Tanpa udara \\
\hline s/d 0,2 & Tidak disadari \\
\hline s/d 0,5 & Nyaman \\
\hline s/d 1 & Disadari/siaga \\
\hline s/d 1,5 & Sensasi dingin \\
\hline$>1,5$ & Mengganggu \\
\hline Su
\end{tabular}

Sumber: Szokolay, 2008

Secara umum kondisi termal tropis basah tidak dirasa nyaman. Karena temperatur udara sering kali mendekati temperatur kulit, pelepasan panas dari tubuh melalui konveksi atau konduksi menjadi sulit juga. Cara utama untuk mendapatkan kenyamanan termal adalah dengan menurunkan panas melalui pergerakan udara (Koenigsberger et al., 1973; Szokolay, 2008). Gerakan udara yang baik akan mengurangi kelembaban udara sehingga panas yang keluar dari tubuh dapat terbawa keluar dan menimbulkan efek pendinginan.

\section{Pergerakan Udara}

Udara bergerak dan mengalir karena arus konveksi alami, yang terjadi karena perbedaan temperatur atau karena perbedaan tekanan udara. Udara bergerak dari tempat bertemperatur rendah ke tinggi atau dari tempat bertekanan tinggi ke rendah. Dapat pula dikatakan udara bergerak dari tekanan udara positif ke negatif (Boutet, 1987; Lechner, 2001).

Terdapat 4 (empat) jenis dasar pergerakan udara yaitu arus berlapis (laminar), terpisah (separate), bergolak (turbulent) dan berpusar (eddy). Pergerakan udara berpusar (eddy) pada kecepatan rendah sering tidak terasa sehingga daerah ini disebut juga daerah tenang (Boutet, 1987).
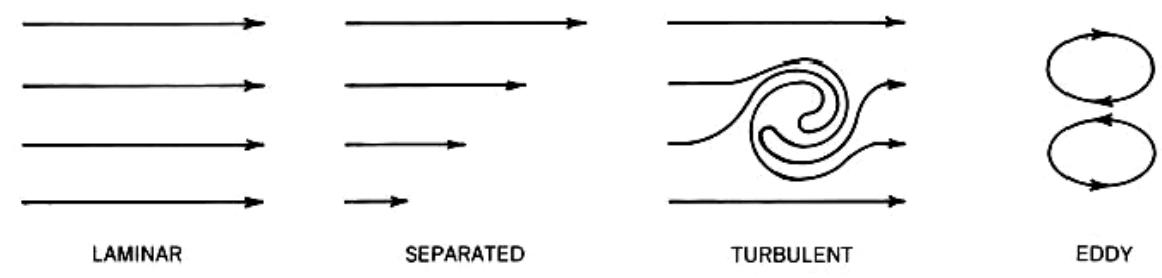

Gambar 2. Empat jenis aliran udara Sumber: Lechner, 2011 


\section{Pergerakan Udara di Sekitar Bangunan}

Ketika pergerakan udara terganggu oleh penghalang, udara akan mencari jalan di sekitar penghalang untuk tetap bergerak. Beberapa prinsip pergerakan angin yang mengenai bangunan dipaparkan pada Tabel 2.

Tabel 2. Prinsip Perilaku Pergerakan Udara di Sekitar Bangunan Perilaku Pergerakan Udara

Daerah bertekanan positif: Penghalang (seperti bangunan) yang menghalangi jalannya angin akan membuat kecepatan angin turun sejenak sebelum mencari jalur baru untuk dilalui. Daerah yang terpengaruh ini disebut daerah dengan tekanan positif (atau tinggi). Pada dinding di daerah ini sebaiknya diberi bukaan masuk (inlet) sehingga udara dapat masuk ke dalam bangunan.

Daerah bertekanan negatif: Ketika aliran udara mengelilingi bangunan, akan tercipta daerah bertekanan negatif (disebut juga bayangan angin). Ukuran dan bentuk daerah ini ditentukan oleh konfigurasi dan ukuran bangunan. Dinding di daerah ini sebaiknya diberi bukaan keluar (outlet) sebagai tempat udara keluar dari bangunan.

Perbedaan tekanan: Perbedaan tekanan (positif dan negatif) membantu menentukan kecepatan angin yang melewati bangunan juga kecepatan angin di luar bangunan, ukuran bukaan (inlet dan outlet) dan perubahan arah pergerakan angin.

\footnotetext{
Perubahan arah: perubahan arah pergerakan angin membutuhkan energi dan mengurangi kecepatannya. Semakin besar kecepatan angin ketika terjadi perubahan arah, semakin besar pula energi yang dibutuhkan dan pengurangan kecepatannya.
}
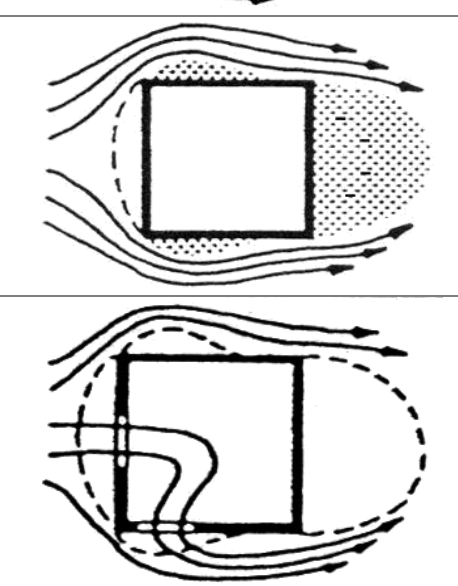

Aliran udara optimum: Bukaan masuk (inlet) dan keluar (outlet) perlu dibuat sebesar mungkin untuk mendapat aliran udara yang optimum. Jika arah angin tegak lurus terhadap inlet dan outlet, angin akan bergerak melewati bangunan dalam arus yang sempit (a). Tidak semua bagian ruangan mendapat pergerakan udara yang signifikan. Arah angin miring akan menghasilkan aliran udara optimum pada area maksimum (b).
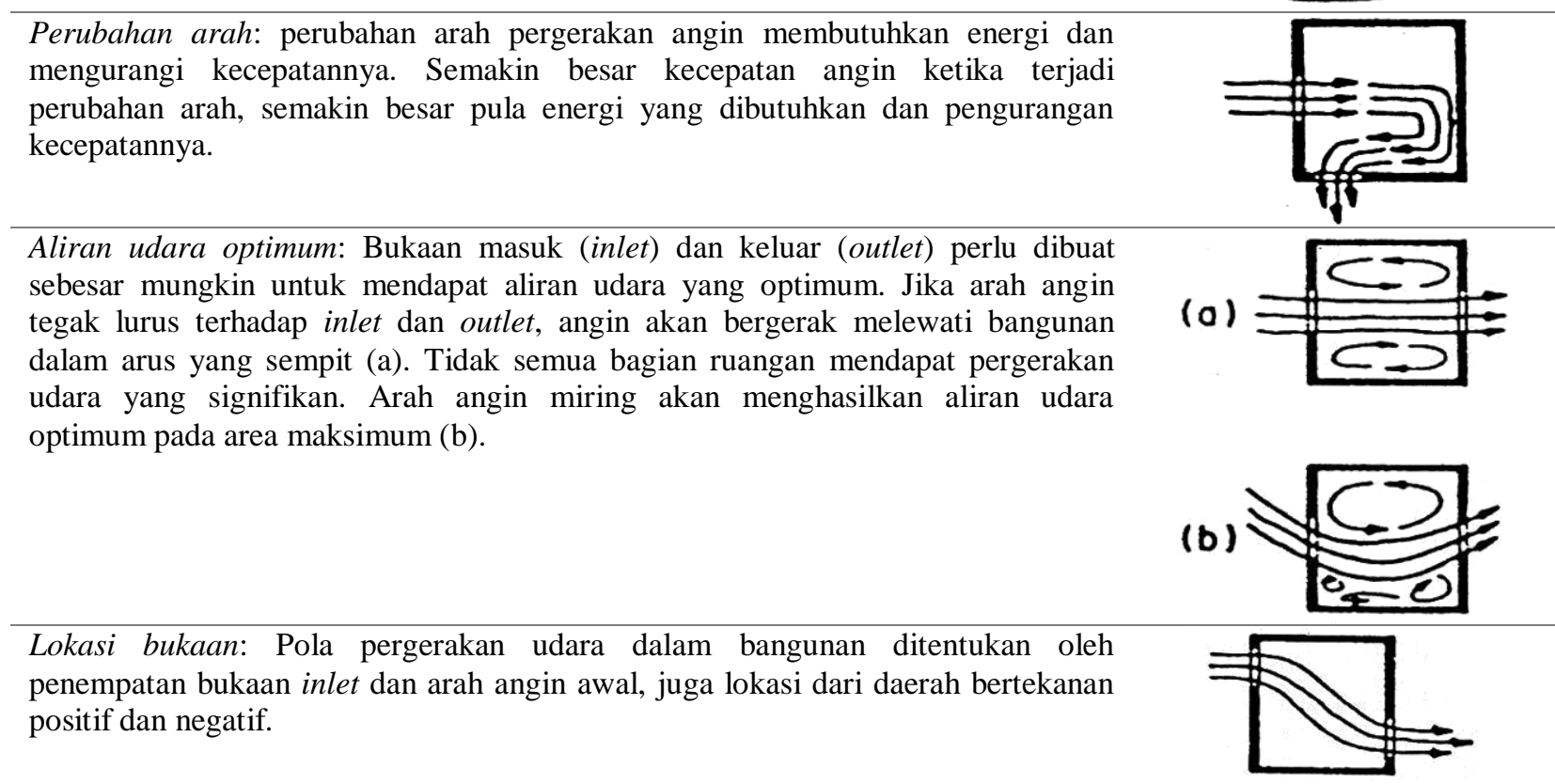

Sumber: Boutet, 1987; Lechner, 2001

\section{Metode Penelitian}

Penelitian ini menggunakan metode deskriptif kuantitatif dengan melakukan pengukuran di lapangan terhadap variabel penelitian yang ditentukan. Langkah-langkah penelitian adalah: 
a. Studi literatur, dilakukan untuk merumuskan permasalahan tentang pergerakan udara dan ventilasi alami pada bangunan.

b. Survei lapangan, dilakukan untuk melihat keadaan termal rumah vernakular melayu Pontianak, juga untuk melihat situasi iklim lapangan secara umum.

c. Melakukan analisis deskriptif kuantitatif terhadap hasil pengukuran yang disusun dalam tabulasi. Analisis dilakukan dengan membandingkan variabel pengukuran, terutama temperatur dan kelajuan angin, yang terjadi pada tiap ruang. Hubungan yang terjadi antar variabel dalam data dilihat untuk kemudian diambil kesimpulan.

Variabel pengukuran adalah aspek kenyamanan termal yaitu:

- Temperatur bola kering (dry bulb temperature/DBT), dalam satuan derajat Celcius

- Temperatur bola basah (wet bulb temperature/WBT), dalam satuan derajat Celcius

- Kelembaban udara relatif (relative humidity/RH), dalam satuan \%

- Temperatur radiasi (globe temperature/GT), dalam satuan derajat Celcius

- Kelajuan angin (velocity/V), dalam satuan m/sekon

Obyek penelitian adalah rumah vernakular melayu di kota Pontianak yang belum banyak mengalami perubahan sejak pertama dibangun. Secara umum tidak dapat ditemukan rumah yang masih benar-benar belum berubah sejak pertama kali dibangun. Umumnya rumah yang masih berdiri mengalami perubahan paling tidak pada penggantian bahan atap, dari kayu sirap atau daun rumbia menjadi atap seng gelombang.

Terdapat dua rumah yang dijadikan obyek penelitian, yaitu:

\section{Rumah 1}

Rumah 1 berada di Jalan Nurali, Kecamatan Pontianak Kota. Rumah ini diperkirakan berumur kurang lebih 130 tahun (berdasarkan wawancara dengan pemilik) dan dipilih karena masih mempertahankan bentuk dan kondisi rumah seperti saat pertama kali dibangun.

Bangunan terletak pada lahan yang cukup luas dan masih terdapat ruang kosong yang cukup antara rumah dengan tetangga. Lahan cukup terbuka tanpa ada banyak vegetasi (pohon) yang mengelilingi rumah.

Rumah terbuat dari struktur kayu dan berupa rumah panggung dengan ketinggian lantai 1,5 m dari muka tanah. Lantai dan dinding terbuat dari kayu (bilah papan) yang tersusun rapat tanpa celah. Atap asli rumah ini adalah atap sirap, namun karena faktor usia bahan, saat ini atap tersebut telah dilapisi dengan seng gelombang. 


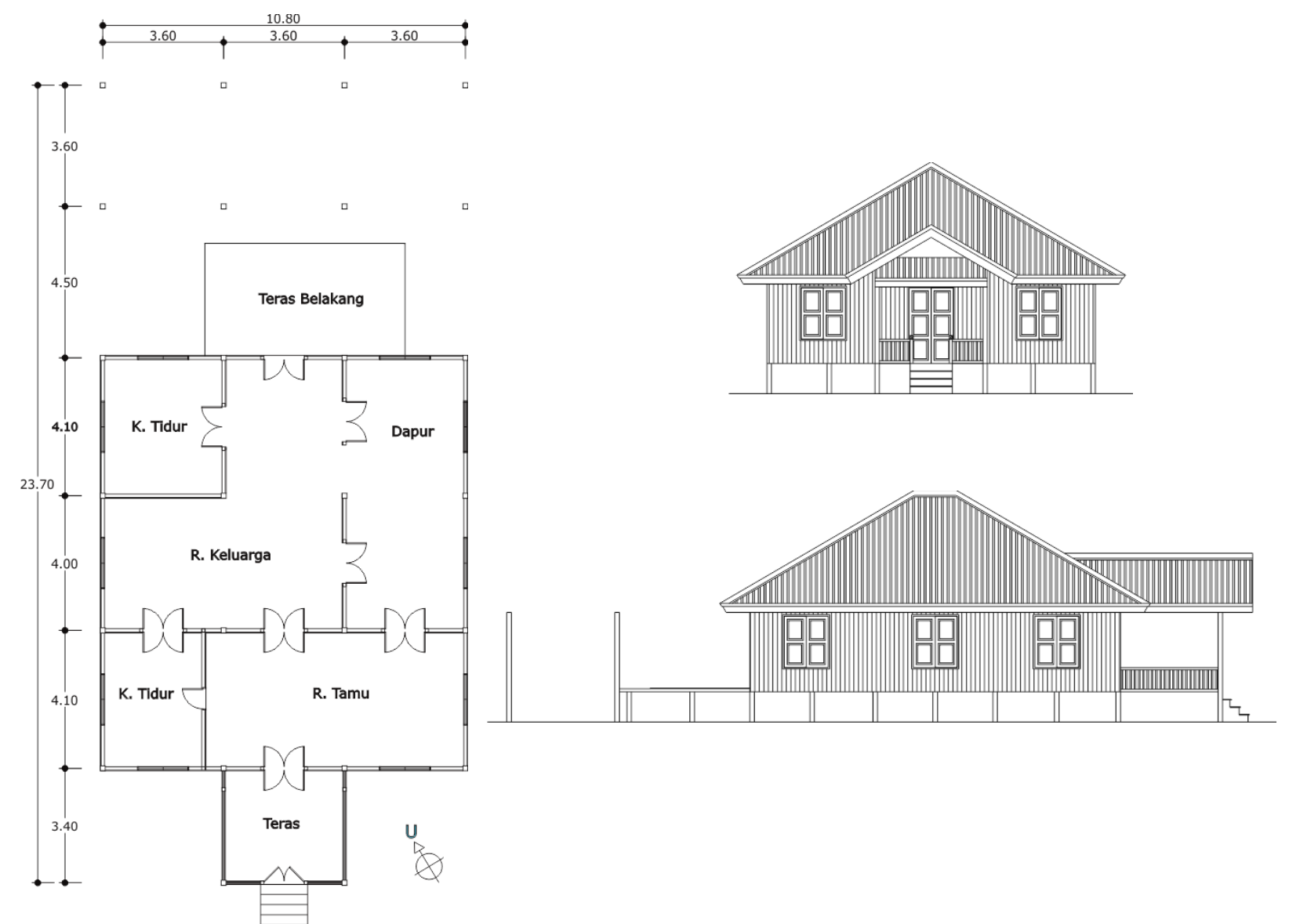

Gambar 3. Denah, tampak depan dan samping kiri Rumah 1 Sumber: Survei lapangan, 2011

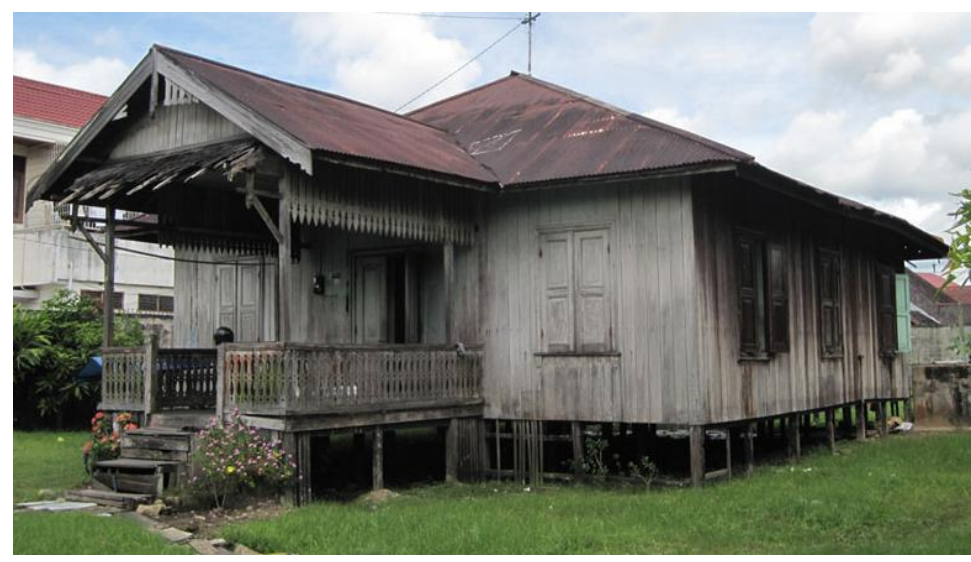

Gambar 4. Tampilan Rumah 1

Sumber: Survei lapangan, 2011

Tata ruang bangunan utama mirip dengan tipikal rumah vernakular melayu, namun bangunan belakang (bangunan anak) yang kemungkinan dulunya berfungsi sebagai dapur, telah hilang. Saat ini hanya terlihat tiang-tiang kayu yang berfungsi sebagai kolom bangunan. Dengan demikian area yang dulunya berupa pelataran belakang sekarang berfungsi seperti teras belakang. 


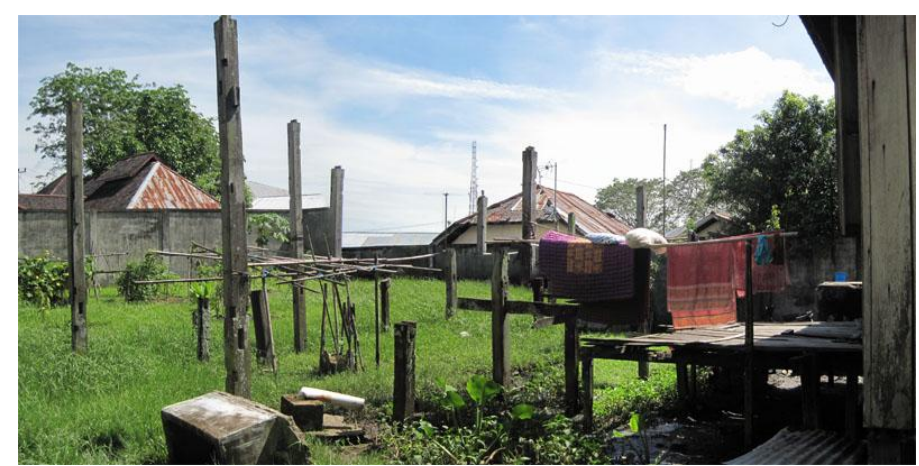

Gambar 5. Situasi bagian belakang rumah, tiang-tiang kayu yang tersisa menunjukkan dulunya terdapat bangunan rumah anak (dapur).

Sumber: Survei lapangan, 2011

Bukaan pintu dan jendela terbuat dari kayu dan memiliki dua daun (pintu dan jendela berbilah ganda dengan bukaan ayun vertikal/vertical pivot), terutama pada pintu dan jendela yang berhubungan langsung dengan ruang luar.

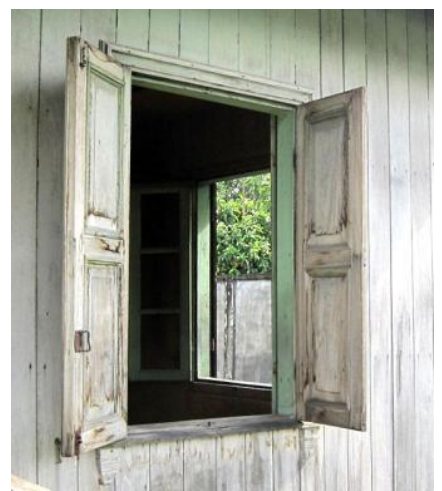

Gambar 6. Jendela dengan bukaan bilah vertikal (vertical pivot window)

Sumber: Survei lapangan, 2011

\section{Rumah 2}

Rumah 2 berada di Jalan Imam Bonjol, Kelurahan Benua Melayu Laut, Kecamatan Pontianak Tenggara, dan terletak di pinggir jalan dekat kawasan tepi sungai yang dulunya juga merupakan perkampungan yang berkembang sejak masa Kesultanan Kadariyah Pontianak (abad ke-18). Rumah ini dibangun pada tahun 1937 dan saat ini relatif masih dalam kondisi dan bentuk seperti saat pertama dibangun.

Lahan rumah cukup panjang dan masih terdapat ruang kosong antara rumah dengan lahan tetangga. Vegetasi atau pepohonan masih cukup banyak mengelilingi rumah. Di bagian depan lahan berdekatan dengan jalan dibangun kios, di depan rumah dibangun garasi motor. Sementara di lahan belakang dekat dapur dibangun kamar mandi dan wc.

Struktur utama bangunan adalah struktur kayu dan berupa rumah panggung dengan ketinggian lantai $2 \mathrm{~m}$ dari muka tanah. Lantai, dinding dan plafon terbuat dari bilah papan kayu yang tersusun rapat tanpa celah. Bahan atap yang dulunya terbuat dari sirap telah diganti dengan seng gelombang.

Tata ruang rumah ini sesuai dengan tipikal rumah vernakular melayu. Bangunan anak di belakang, yang berfungsi sebagai dapur, masih ada sehingga pelataran belakang yang membatasi bangunan utama dan dapur pun masih ada. Karena penambahan anggota keluarga, beberapa ruang kamar tidur ditambahkan dengan memberikan sekat dinding tripleks di beberapa tempat. 


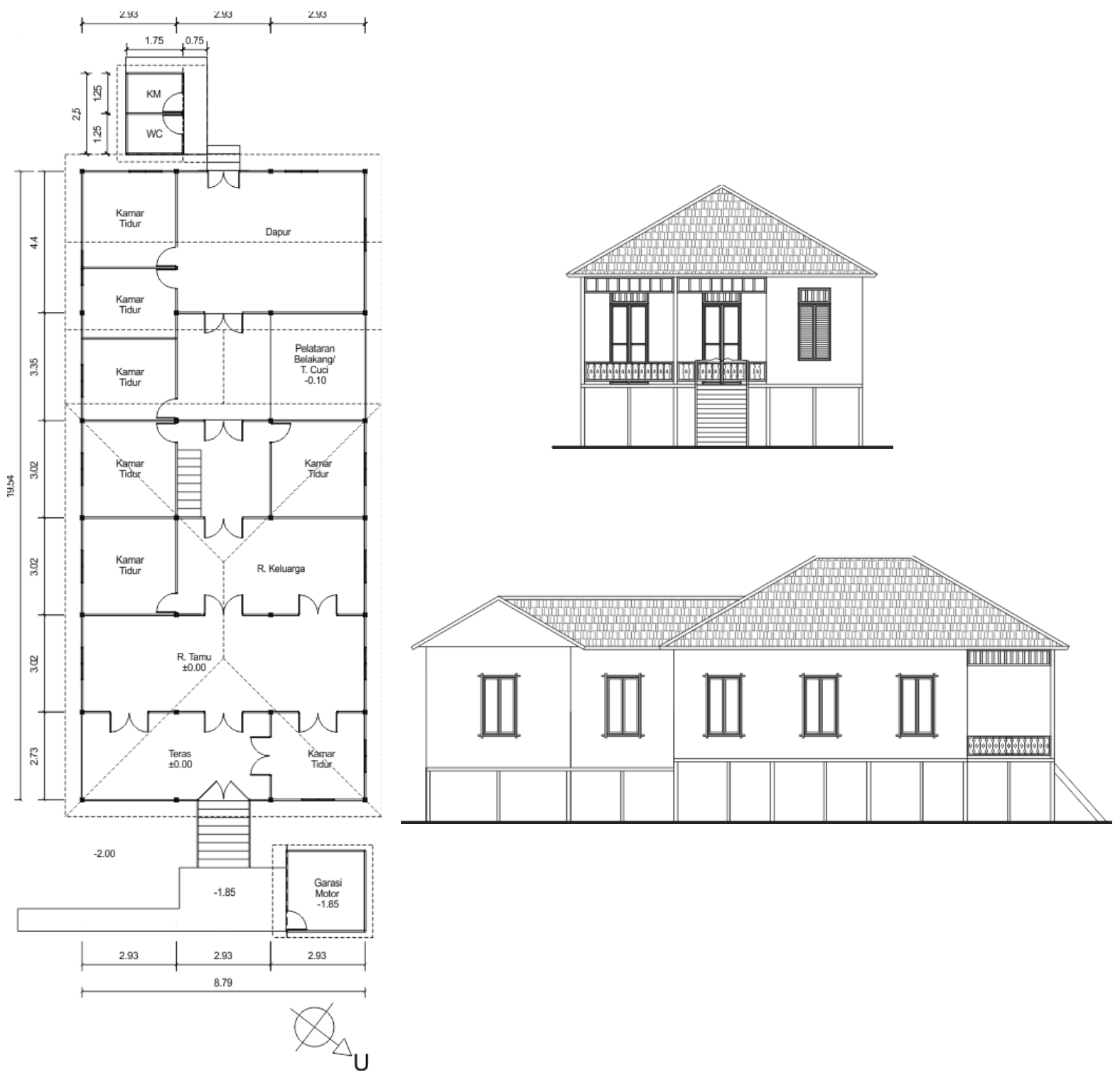

Gambar 7. Denah, tampak depan dan samping kiri Rumah 2

Sumber: Survei lapangan, 2011

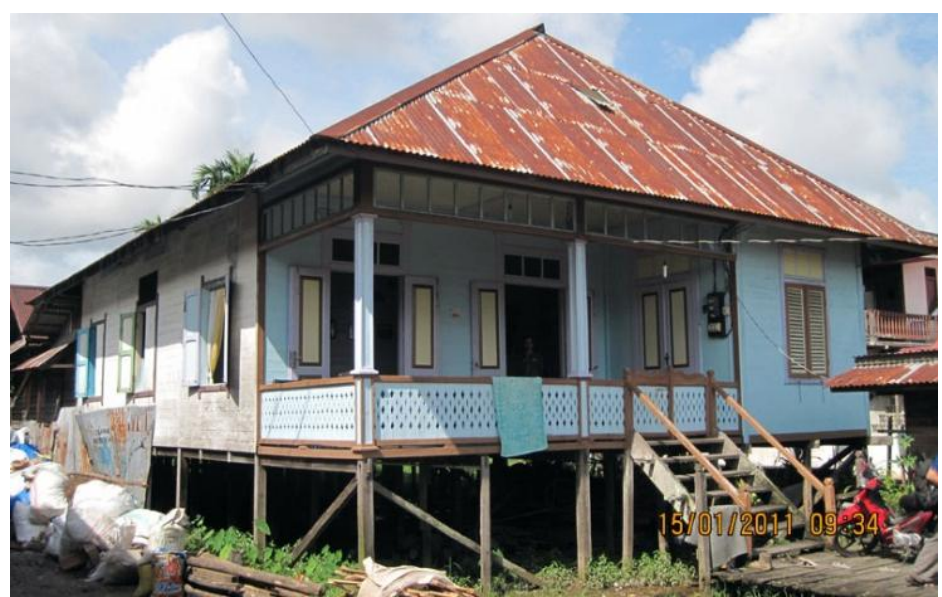

Gambar 8. Tampilan Rumah 2

Sumber: Survei lapangan, 2011 
Bukaan berupa pintu dan jendela terbuat dari kayu dan memiliki dua daun (pintu dan jendela berbilah ganda dengan bukaan ayun vertikal/vertical pivot), terutama pada pintu dan jendela yang berhubungan langsung dengan ruang luar.

Bentuk dan kondisi rumah yang relatif masih sesuai dengan keadaan awal dianggap akan mewakili kondisi termal dan pergerakan angin pada rumah vernakular Pontianak dengan ruang pelataran belakang.
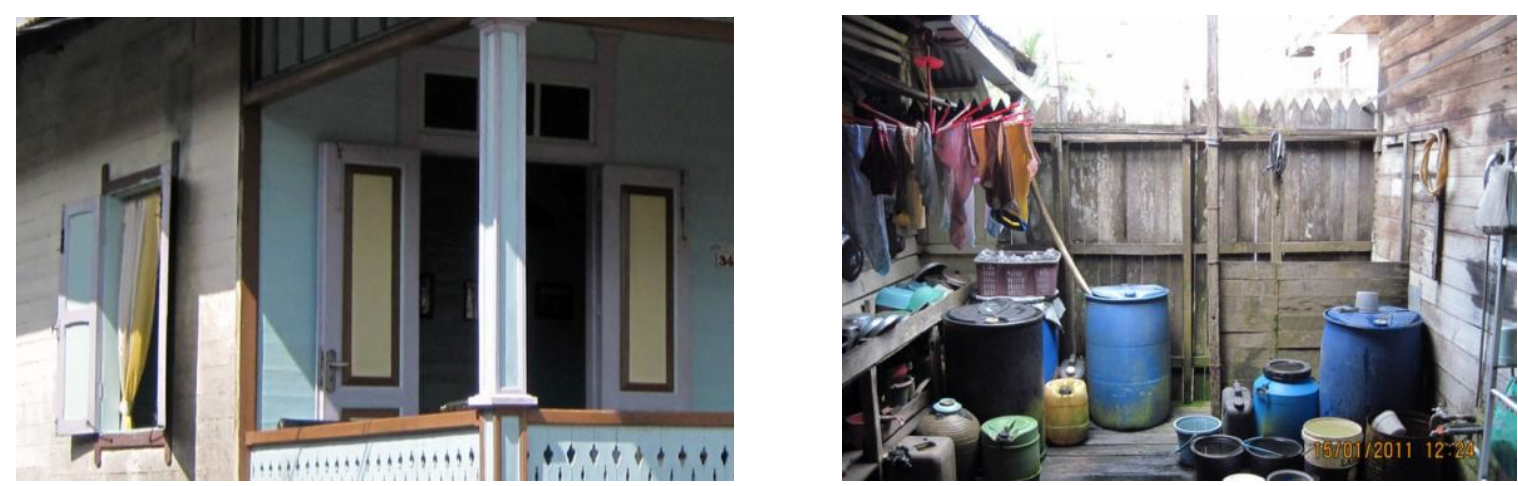

Gambar 9. Bukaan pintu dan jendela (kiri) dan suasana pelataran belakang, difungsikan sebagai tempat cuci (kanan)

Sumber: Survei lapangan, 2011

Peralatan yang digunakan untuk mengukur variabel di lapangan adalah berupa alat manual dan elektronik, yaitu termometer bola kering dan bola basah, termometer bola hitam, hot wire anemometer, alat ukur digital 4-in-1 (Gambar 10).

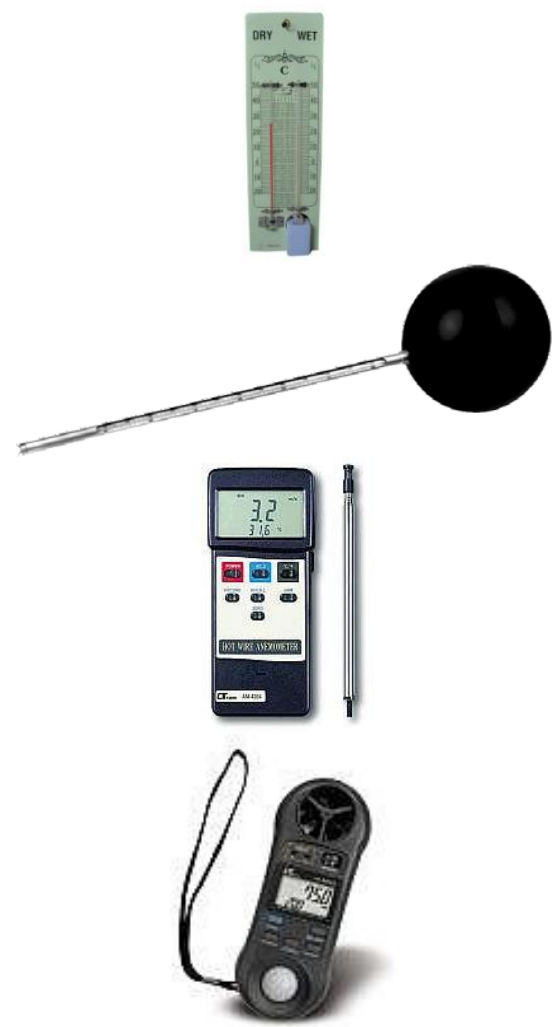

Termometer Bola Kering dan Bola Basah Yenaco

Digunakan untuk mengukur temperatur bola kering (DBT)

dan temperatur bola basah (WBT) di ruang dalam

Termometer Bola Hitam

Digunakan untuk mengukur temperatur radiasi (GT) di

ruang dalam dan ruang luar

\title{
Lutron AM-4204
}

Hot Wire Anemometer

Digunakan untuk mengukur kelajuan angin di ruang dalam

Gambar 10. Alat ukur survei lapangan

Sumber: Dokumentasi, 2011

\author{
Lutron LM-8000 \\ 4-in-1 Anemometer, Humidity meter, Light Meter, Type \\ K Thermometer \\ Digunakan untuk mengukur temperatur udara, \\ kelembaban udara relatif dan kelajuan angin di ruang luar
}


Waktu pengukuran dilakukan selama siang hari pada tanggal 4 Januari 2011 di Rumah 1 dan tanggal 15 Januari 2011 di Rumah 2 dengan keadaan bukaan terbuka. Pengukuran dilakukan dengan interval tiap satu jam mulai jam 07.00 sampai dengan jam 18.00 dengan pencatatan kondisi cuaca saat pengukuran.

Pengukuran dilakukan di ruang dalam dan ruang luar pada masing-masing rumah. Titik ukur (TU) ditentukan di daerah-daerah yang dianggap mewakili posisi data yang dibutuhkan. Baik pada Rumah 1 maupun Rumah 2, TU ditempatkan pada sumbu tengah masing-masing ruangan. Ketinggian titik ukur adalah 1,5 m dari lantai (atau tanah, untuk ruang luar), menyesuaikan dengan posisi aktivitas manusia. Penyebaran titik ukur Rumah 1 dan Rumah 2 dapat dilihat pada Gambar 11.
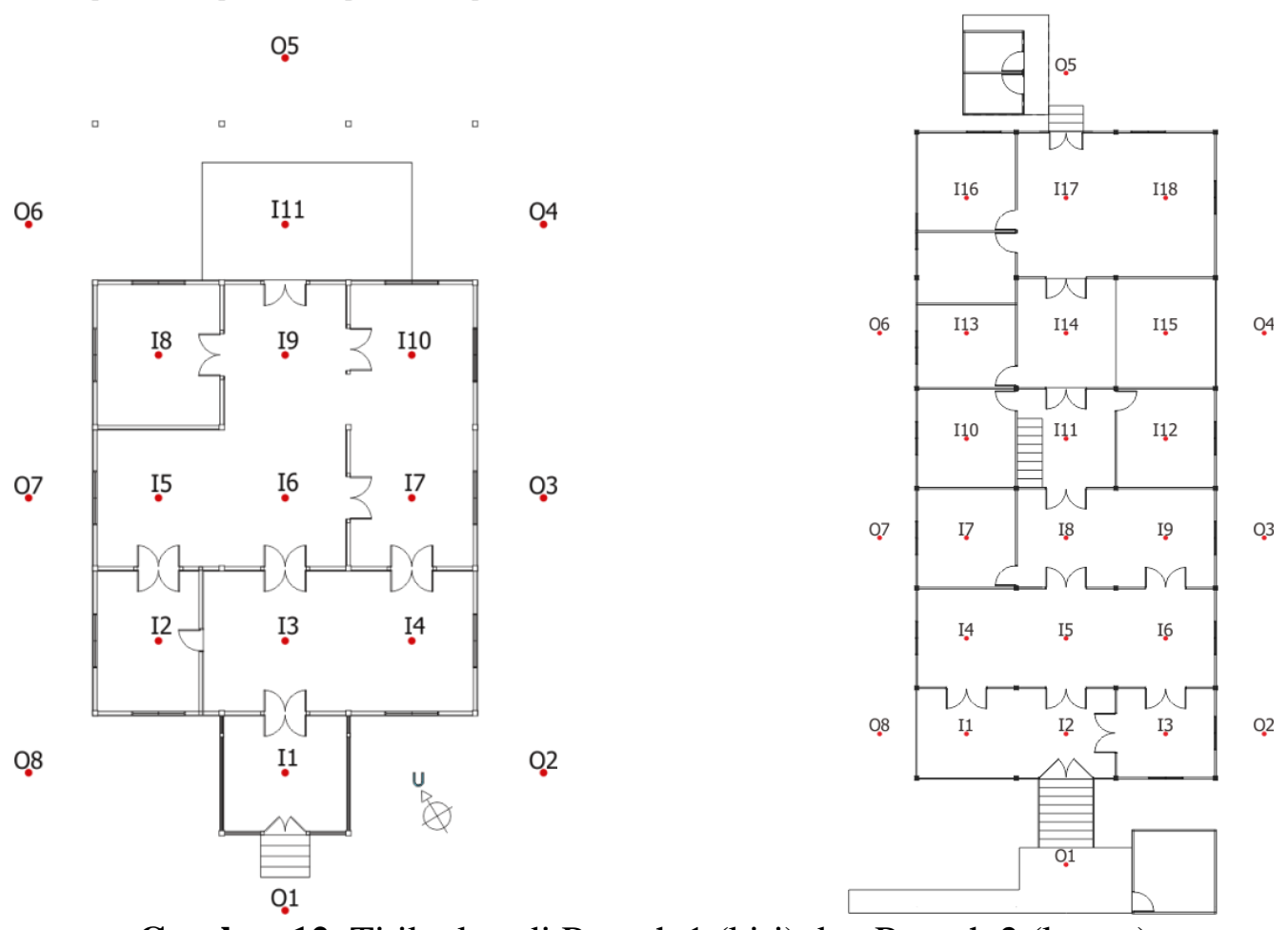

Gambar 12. Titik ukur di Rumah 1 (kiri) dan Rumah 2 (kanan)

Sumber: Analisis, 2011

\section{Hasil dan Pembahasan}

Pengolahan data yang didapat dari pengukuran di Rumah 1 dan Rumah 2 dilakukan dengan analisis kuantitatif, yaitu dengan mencari rata-rata masing-masing variabel pengukuran dan selanjutnya ditampilkan dalam bentuk grafik bagi kepentingan analisis.

Data hasil pengukuran merupakan rata-rata kelajuan udara (V), temperatur bola kering (dry bulb temperature [DBT]), temperatur bola basah (wet bulb temperature [WBT]), kelembaban udara relatif (relative humidity $[\mathrm{RH}]$ ) dan temperatur radiasi (globe temperature [GT]) tiap jam pengukuran dan tiap titik pengukuran.

Analisis dilakukan dengan menginterpretasi data rata-rata hasil pengukuran lapangan secara kuantitatif dengan menginterpretasi data numerik. Analisis dilakukan terutama pada hasil pengukuran temperatur bola kering, karena variabel temperatur adalah variabel yang paling menentukan dalam sensasi kenyamanan termal yang dirasakan, dan pengukuran kelajuan angin, karena di iklim tropis lembab kelajuan angin adalah variabel yang paling mungkin dimodifikasi untuk mendapatkan kenyamanan termal. 


\section{Hasil Pengukuran}

Pengukuran pada Rumah 1 dilakukan pada hari Selasa, 4 Januari 2011. Cuaca pada saat pengukuran cerah pada pagi hari, kemudian berawan dan sedikit hujan gerimis saat siang hari, kemudian kembali cerah menjelang sore hari. Rata-rata temperatur ruang dalam (DBT) adalah 29,77 ${ }^{\circ} \mathrm{C}$, lebih rendah daripada ruang luar sebesar $31,44{ }^{\circ} \mathrm{C}$. Kelembaban rata-rata dalam bangunan cukup tinggi yaitu sebesar $88,34 \%$ sementara di luar lebih rendah yaitu 78,93\%. Kondisi temperatur radiasi di ruang dalam secara signifikan lebih rendah, yaitu $29,99^{\circ} \mathrm{C}$, dibandingkan ruang luar sebesar 34,32 ${ }^{\circ} \mathrm{C}$. Rata-rata kelajuan angin di ruang dalam adalah $0,35 \mathrm{~m} / \mathrm{s}$, lebih rendah dari ruang luar sebesar $0,98 \mathrm{~m} / \mathrm{s}$.

Pengukuran pada Rumah 2 dilakukan pada hari Sabtu, 15 Januari 2011. Cuaca pada saat pengukuran pada umumnya cerah. Rata-rata temperatur ruang dalam (DBT) adalah $29,51{ }^{\circ} \mathrm{C}$, lebih rendah daripada ruang luar sebesar $30,74{ }^{\circ} \mathrm{C}$. Kelembaban rata-rata dalam bangunan juga cukup tinggi yaitu sebesar $86,17 \%$ sementara di luar lebih rendah yaitu 77,93\%. Kondisi temperatur radiasi di ruang dalam lebih rendah, yaitu $29,37{ }^{\circ} \mathrm{C}$, dibandingkan ruang luar sebesar $31,93{ }^{\circ} \mathrm{C}$. Rata-rata kelajuan angin di ruang dalam adalah $0,28 \mathrm{~m} / \mathrm{s}$, lebih rendah dari ruang luar sebesar $0,77 \mathrm{~m} / \mathrm{s}$.

\section{A. Rumah 1}

Rata-rata temperatur (DBT) ruang dalam lebih rendah dari ruang luar dan fluktuasinya mengikuti pergerakan temperatur ruang luar. Namun di ruang dalam cukup stabil, karena ketika ruang luar mengalami kenaikan temperatur yang cukup tinggi yaitu $2,1{ }^{\circ} \mathrm{C}$ (dari jam 08.00 sampai 09.00), ruang dalam hanya mengalami kenaikan sebesar $0,76{ }^{\circ} \mathrm{C}$. Demikian pula saat terjadi penurunan di ruang luar sebesar $1,85^{\circ} \mathrm{C}$ (jam 10.00 sampai jam 11.00), ruang dalam hanya mengalami penurunan $0,52{ }^{\circ} \mathrm{C}$.

Saat temperatur ruang luar mencapai maksimal yaitu $34,17^{\circ} \mathrm{C}$, temperatur ruang dalam masih memiliki perbedaan cukup tinggi yaitu sebesar $2,63{ }^{\circ} \mathrm{C}$ (temperatur ruang dalam adalah 31,54 $\left.{ }^{\circ} \mathrm{C}\right)$. Setelah mencapai kondisi maksimal pada jam 14.00, temperatur ruang luar kemudian turun diikuti oleh temperatur ruang dalam dan semakin sore temperatur ruang dalam cenderung sama dengan temperatur ruang luar.

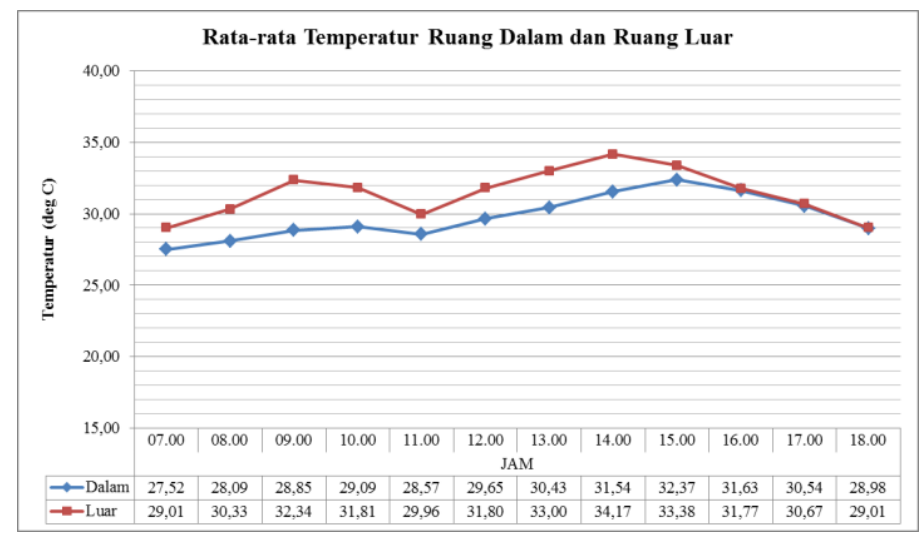

Gambar 13. Perbandingan perubahan temperatur bola kering (DBT) selama satu hari di ruang luar dan dalam bangunan Rumah 1.

Sumber: Analisis, 2011

Rata-rata kelajuan angin ruang luar $(0,98 \mathrm{~m} / \mathrm{s})$ lebih tinggi daripada di dalam bangunan $(0,35$ $\mathrm{m} / \mathrm{s}$ ) namun perubahan kelajuan di ruang luar cenderung diikuti oleh kelajuan angin di ruang dalam. Hal ini menunjukkan bahwa terjadi ventilasi alami yang cukup baik di dalam bangunan karena kelajuan angin yang terjadi di dalam bangunan dipengaruhi oleh kelajuan angin yang terjadi di ruang luar. 


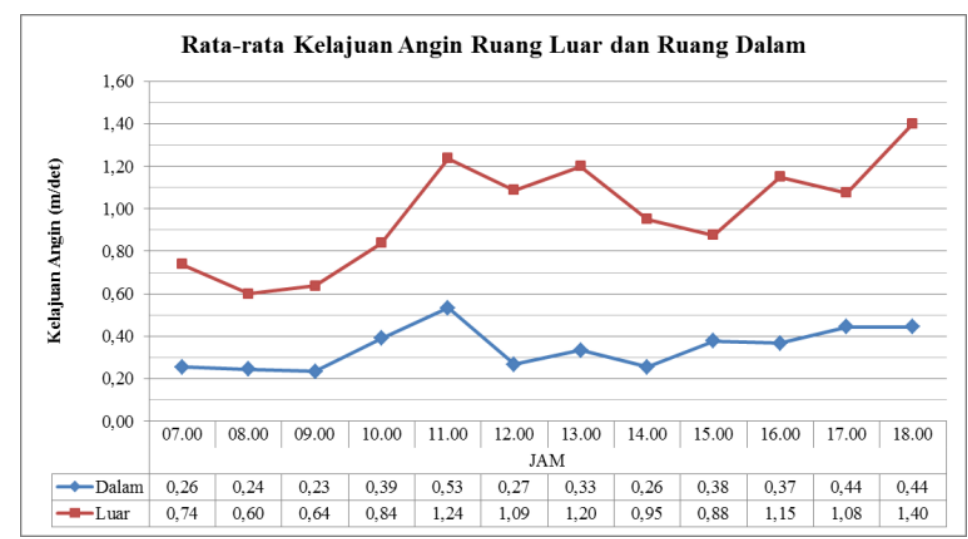

Gambar 14. Perbandingan perubahan kelajuan angin (V) selama satu hari di ruang luar dan dalam bangunan Rumah 1.

Sumber: Analisis, 2011

Untuk mendukung hipotesis penelitian, dilihat pula perbandingan antara beberapa titik ukur yang terdapat di ruang luar, teras, pelataran dan ruang dalam bangunan induk. Untuk Rumah 1 , pembagian titik ukur yang akan dibandingkan terlihat pada Gambar 15 dan perbandingan hasil antar titik ukur tersebut terlihat pada Tabel 3 dan Tabel 4.

Terjadi penurunan temperatur secara bertahap dari ruang luar $\left(31,44{ }^{\circ} \mathrm{C}\right)$, lalu di teras, baik teras depan $\left(30,26{ }^{\circ} \mathrm{C}\right)$ maupun teras belakang $\left(30,9^{\circ} \mathrm{C}\right)$, sampai ke dalam rumah $\left(29,3{ }^{\circ} \mathrm{C}\right.$ dan $29,96{ }^{\circ} \mathrm{C}$ ). Hal ini menunjukkan bahwa teras cukup berperan dalam menurunkan panas yang masuk ke dalam bangunan. Rata-rata temperatur di ruang tengah (I6 dan I9) adalah $29,3{ }^{\circ} \mathrm{C}$, lebih kecil daripada ruang tamu (I3 dan I4) yaitu $29,96{ }^{\circ} \mathrm{C}$.

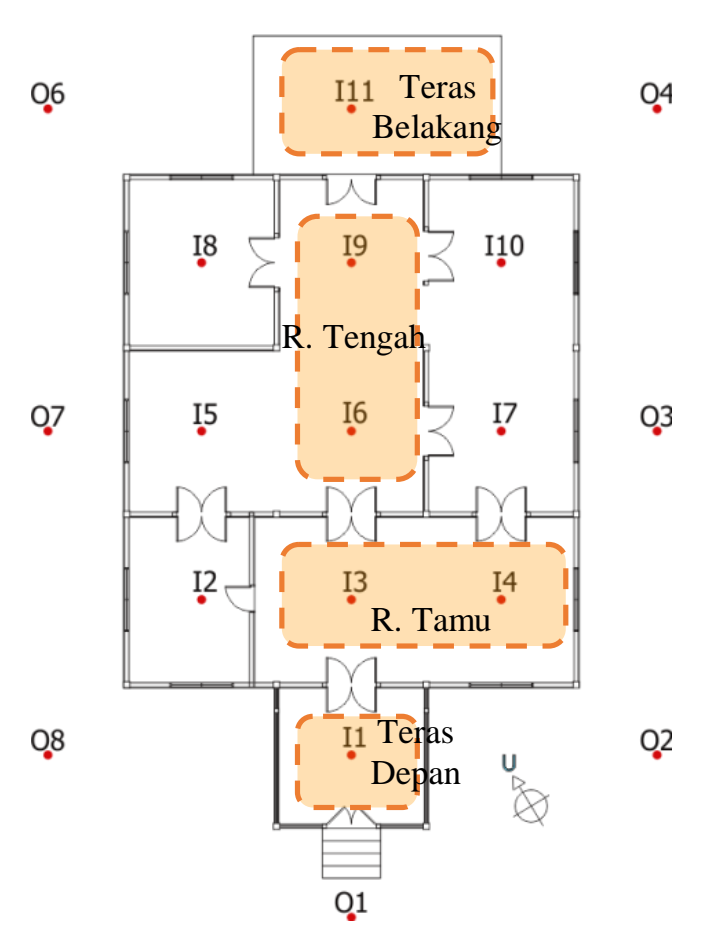

Gambar 15. Zona titik ukur untuk analisis pengaruh teras/pelataran pada kondisi ruang dalam di Rumah 1.

Sumber: Analisis, 2011 
Tabel 3. Perbandingan Temperatur Bola Kering $\left({ }^{\circ} \mathrm{C}\right)$ Antar Ruang Rumah 1

\begin{tabular}{|c|c|c|c|c|c|c|c|c|c|c|c|c|c|}
\hline \multirow{2}{*}{ Titik Ukur } & \multicolumn{12}{|c|}{ JAM } & \multirow{2}{*}{$\begin{array}{l}\text { Rata- } \\
\text { rata }\end{array}$} \\
\hline & 07.00 & 8.00 & 09.00 & 10.00 & 11.00 & 12.00 & 13.00 & 14.00 & 15.00 & 16.00 & 17.00 & 18.00 & \\
\hline $\begin{array}{l}\text { Teras } \\
\text { Depan }\end{array}$ & 27,9 & 28,9 & 28,9 & 29,4 & 28,9 & 30,9 & 30,9 & 32,4 & 32,9 & 31,9 & 30,9 & 29,4 & 30,26 \\
\hline R. Tam & & & & & & & & & 32,9 & & 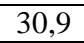 & 29 & 29,96 \\
\hline R. TeI & 26,7 & 27,4 & 28,2 & 28,7 & 28,7 & 28,9 & 29,9 & 30,2 & 32,2 & 31,4 & 30,4 & 28,7 & 29,30 \\
\hline Teras Blkg & 30,3 & 29,3 & 30,8 & 29,3 & 28,3 & 31,3 & 33,3 & 35,3 & 32,3 & 31,8 & 30,3 & 28,3 & 30,90 \\
\hline Rata2 Luar & 29,01 & 30,33 & 32,34 & 31,81 & 29,96 & 31,8 & 33 & 34,17 & 33,38 & 31,77 & 30,67 & 29,01 & 31,44 \\
\hline
\end{tabular}

Sumber: Analisis, 2011

Tabel 4. Perbandingan Kelajuan Angin (m/s) Antar Ruang Rumah 1

\begin{tabular}{|c|c|c|c|c|c|c|c|c|c|c|c|c|c|}
\hline \multirow{2}{*}{ Titik Ukur } & \multicolumn{12}{|c|}{ JAM } & \multirow{2}{*}{$\begin{array}{c}\text { Rata- } \\
\text { rata }\end{array}$} \\
\hline & 07.00 & 08.00 & 09.00 & 10.00 & 11.00 & 12.00 & 13.00 & 14.00 & 15.00 & 16.00 & 17.00 & 18.00 & \\
\hline $\begin{array}{l}\text { Teras } \\
\text { Depan }\end{array}$ & 0,1 & 0,1 & 0,6 & 0,6 & 0,6 & 0,1 & 0,5 & 0,3 & 0,4 & 0,8 & 0,8 & 1,2 & 0,51 \\
\hline R. Tamu & 0,1 & 0,2 & 0,2 & 0,3 & 0,4 & 0,2 & 0,3 & 0,2 & 0,4 & 0,5 & 0,4 & 0,6 & 0,30 \\
\hline R. Tengah & 0,3 & 0,3 & 0,2 & 0,3 & 0,5 & 0,3 & 0,4 & 0,2 & 0,4 & 0,3 & 0,4 & 0,3 & 0,30 \\
\hline Teras Blkg & 0,6 & 0,8 & 0,4 & 0,8 & 1,6 & 0,7 & 0,9 & 0,6 & 0,7 & 0,4 & 0,7 & 0,6 & 0,73 \\
\hline Rata2 Luar & 0,74 & 0,60 & 0,64 & 0,84 & 1,24 & 1,09 & 1,20 & 0,95 & 0,88 & 1,15 & 1,08 & 1,40 & 0,98 \\
\hline
\end{tabular}

Sumber: Analisis, 2011

Kelajuan angin juga menurun secara bertahap dari ruang luar $(0,98 \mathrm{~m} / \mathrm{s})$ ke teras depan $(0,51$ $\mathrm{m} / \mathrm{s})$ dan teras belakang $(0,73 \mathrm{~m} / \mathrm{s})$ lalu ke ruang dalam $(0,3 \mathrm{~m} / \mathrm{s})$. Kelajuan di ruang dalam, di ruang tamu dan ruang tengah, relatif sama yaitu sebesar $0,3 \mathrm{~m} / \mathrm{s}$. Jika dilihat dari grafik kelajuan angin selama satu hari (Gambar 17), terlihat bahwa kelajuan angin di teras, baik teras depan maupun belakang bergerak mengikuti kelajuan angin di ruang luar dan hal ini mempengaruhi kelajuan angin yang terjadi di ruang dalam.

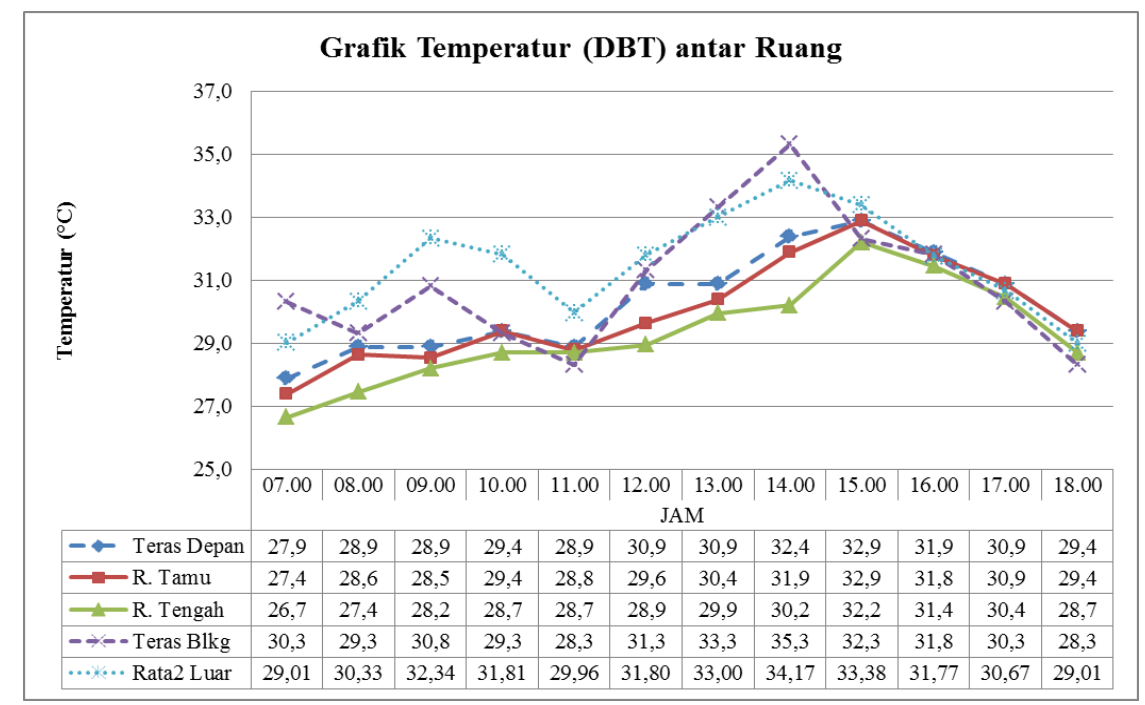

Gambar 16. Grafik perbandingan temperatur antar ruang pada Rumah 1

Sumber: Analisis, 2011 


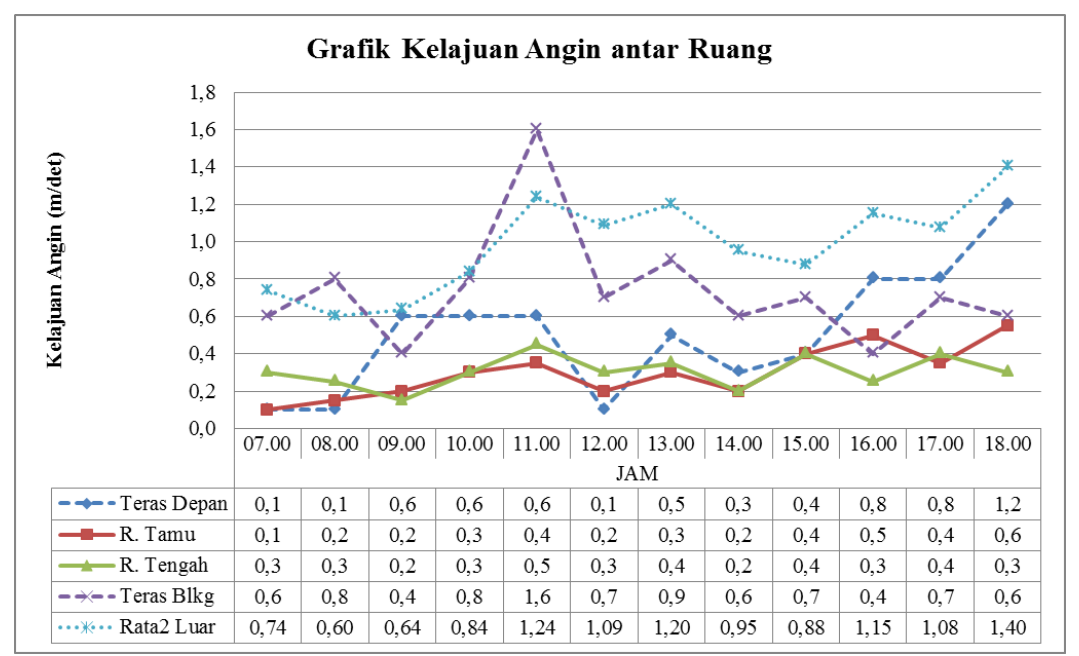

Gambar 17. Grafik perbandingan kelajuan angin antar ruang pada Rumah 1

Sumber: Analisis, 2011

\section{B. Rumah 2}

Rata-rata temperatur (DBT) ruang dalam $\left(29,51^{\circ} \mathrm{C}\right)$ di Rumah 2 lebih rendah dari ruang luar $\left(30,74{ }^{\circ} \mathrm{C}\right)$ dan fluktuasinya juga mengikuti pergerakan temperatur ruang luar. Sampai dengan siang hari (jam 12.00) perbedaan temperatur antara ruang dalam dan ruang luar cukup tinggi. Setelah itu temperatur di dalam bangunan cenderung mengikuti temperatur ruang luar.

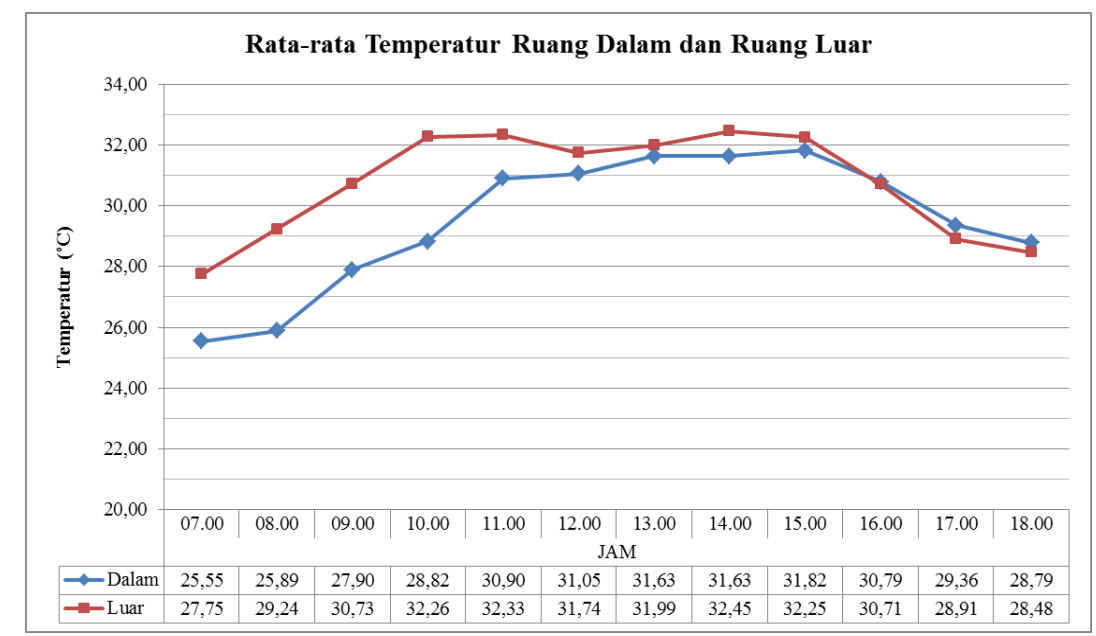

Gambar 18. Perbandingan perubahan temperatur bola kering (DBT) selama satu hari di ruang luar dan dalam bangunan Rumah 2.

Sumber: Analisis, 2011

Seperti halnya di Rumah 1, rata-rata kelajuan angin ruang luar $(0,77 \mathrm{~m} / \mathrm{s})$ lebih tinggi daripada di dalam bangunan $(0,28 \mathrm{~m} / \mathrm{s})$ dan perubahan kelajuan di ruang luar cenderung diikuti oleh kelajuan angin di ruang dalam. Hal ini menunjukkan bahwa terjadi ventilasi alami yang cukup baik di dalam bangunan karena kelajuan angin yang terjadi di dalam bangunan dipengaruhi kelajuan angin yang terjadi di ruang luar. 


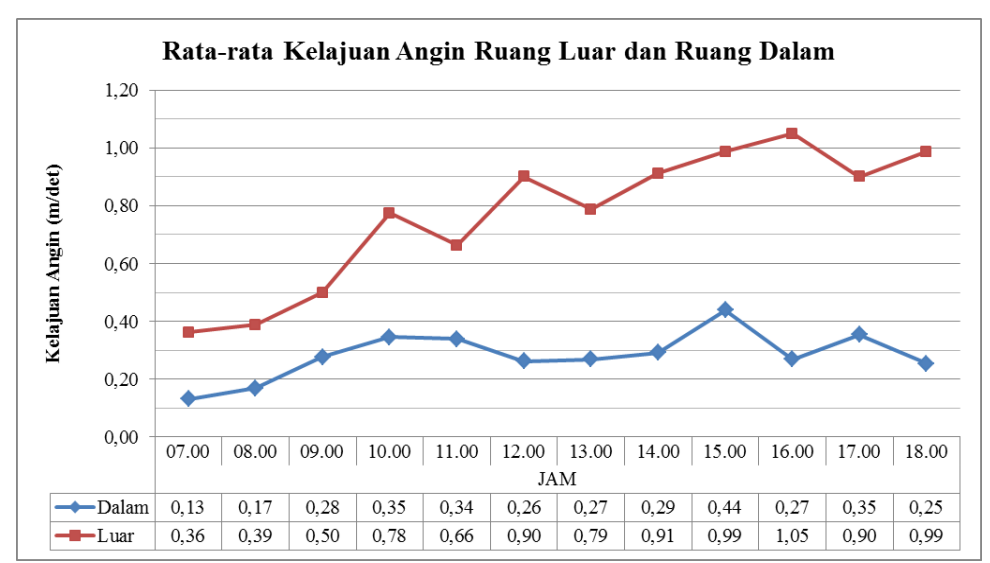

Gambar 19. Perbandingan perubahan kelajuan angin (V) selama satu hari di ruang luar dan dalam bangunan Rumah 2.

Sumber: Analisis, 2011

Perbandingan dilakukan juga pada beberapa titik ukur yang terdapat di ruang luar, teras, pelataran dan ruang dalam bangunan induk. Untuk Rumah 2, pembagian titik ukur yang akan dibandingkan terlihat pada Gambar 20 dan perbandingan antar ruang tersebut terlihat pada Tabel 5 dan Tabel 6.

Seperti halnya Rumah 1 , terjadi penurunan temperatur secara bertahap dari ruang luar $(30,74$ $\left.{ }^{\circ} \mathrm{C}\right)$, lalu di teras depan $\left(29,84{ }^{\circ} \mathrm{C}\right)$, sampai ke dalam rumah (paling rendah $29,09{ }^{\circ} \mathrm{C}$ di ruang tengah). Pada ruang dalam, temperatur rata-rata paling rendah terdapat pada zona ruang tengah (I8 dan I11) sebesar $29,09^{\circ} \mathrm{C}$. Zona ini merupakan zona yang dianggap sebagai tempat utama aliran udara dalam bangunan.

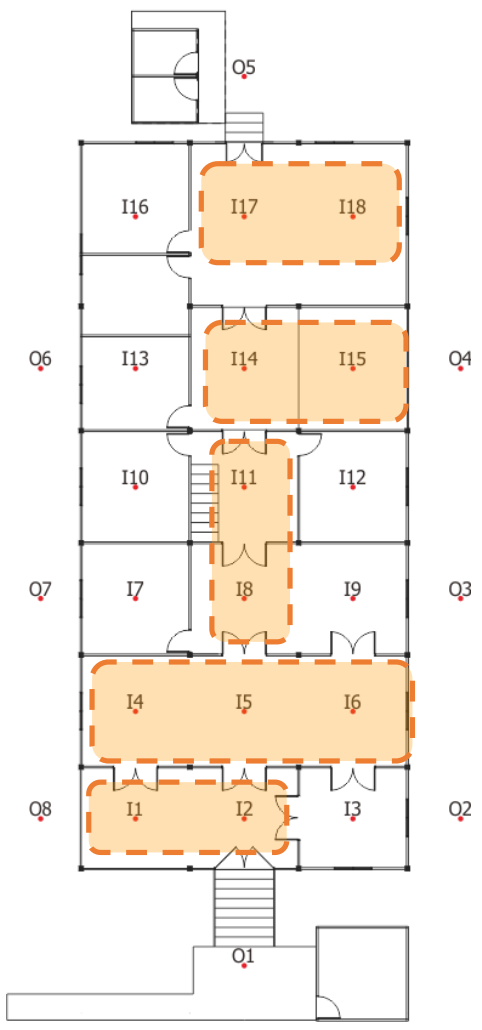

Gambar 20. Zona titik ukur untuk analisis pengaruh teras/pelataran pada kondisi ruang dalam di Rumah 2.

Sumber: Analisis, 2011 
Tabel 5. Perbandingan Temperatur Bola Kering $\left({ }^{\circ} \mathrm{C}\right)$ Antar Ruang Rumah 2

\begin{tabular}{|c|c|c|c|c|c|c|c|c|c|c|c|c|c|}
\hline \multirow{2}{*}{ Titik Ukur } & \multicolumn{12}{|c|}{ JAM } & \multirow{2}{*}{$\begin{array}{l}\text { Rata- } \\
\text { rata }\end{array}$} \\
\hline & 07.00 & 08.00 & 09.00 & 10.00 & 11.00 & 12.00 & 13.00 & 14.00 & 15.00 & 16.00 & 17.00 & 18.00 & \\
\hline Teras Depan & 25,4 & 26,4 & 28,4 & 28,9 & 31,9 & 31,9 & 31,9 & 31,9 & 31,9 & 30,9 & 29,9 & 28,9 & 29,84 \\
\hline R. Tamu & 25,4 & 25,9 & 27,9 & 28,4 & 31,2 & 30,7 & 31,4 & 31,9 & 31,9 & 30,9 & 29,9 & 28,9 & 29,52 \\
\hline R. Tengah & 25,2 & 25,6 & 27,6 & 28,6 & 30,6 & 30,3 & 31,1 & 31,1 & 31,3 & 30,3 & 28,8 & 28,6 & 29,09 \\
\hline $\begin{array}{l}\text { Pelataran } \\
\text { Belakang }\end{array}$ & 25,8 & 25,7 & 27,8 & 28,8 & 29,8 & 31,3 & 31,8 & 31,8 & 31,8 & 30,8 & 29,1 & 28,3 & 29,40 \\
\hline Dapur & 25,9 & 25,9 & 27,8 & 29,3 & 30,8 & 31,3 & 32,1 & 31,8 & 32,3 & 30,8 & 29,1 & 28,8 & 29,66 \\
\hline Rata2 Luar & 27,8 & 29,2 & 30,7 & 32,3 & 32,3 & 31,7 & 32,0 & 32,5 & 32,3 & 30,7 & 28,9 & 28,5 & 30,74 \\
\hline
\end{tabular}

Sumber: Analisis, 2011

Tabel 6. Perbandingan Kelajuan Angin (m/s) Antar Ruang Rumah 2

\begin{tabular}{|c|c|c|c|c|c|c|c|c|c|c|c|c|c|}
\hline \multirow{2}{*}{ Titik Ukur } & \multicolumn{12}{|c|}{ JAM } & \multirow{2}{*}{$\begin{array}{l}\text { Rata- } \\
\text { rata }\end{array}$} \\
\hline & 07.00 & 08.00 & 09.00 & 10.00 & 11.00 & 12.00 & 13.00 & 14.00 & 15.00 & 16.00 & 17.00 & 18.00 & \\
\hline Teras Depan & 0,10 & 0,10 & 0,35 & 0,50 & 0,90 & 0,60 & 0,25 & 0,25 & 0,50 & 0,25 & 0,45 & 0,20 & 0,37 \\
\hline R. Tamu & 0,10 & 0,13 & 0,33 & 0,10 & 0,10 & 0,27 & 0,20 & 0,20 & 0,27 & 0,20 & 0,30 & 0,17 & 0,20 \\
\hline R. Tengah & 0,25 & 0,25 & 0,20 & 0,25 & 0,40 & 0,35 & 0,20 & 0,45 & 0,55 & 0,20 & 0,45 & 0,40 & 0,33 \\
\hline $\begin{array}{l}\text { Pelataran } \\
\text { Belakang }\end{array}$ & 0,25 & 0,20 & 0,25 & 0,65 & 0,45 & 0,10 & 0,35 & 0,25 & 0,55 & 0,40 & 0,45 & 0,25 & 0,35 \\
\hline Dapur & 0,10 & 0,25 & 0,35 & 0,30 & 0,25 & 0,10 & 0,35 & 0,20 & 0,50 & 0,35 & 0,40 & 0,40 & 0,30 \\
\hline Rata2 Luar & 0,36 & 0,39 & 0,50 & 0,78 & 0,66 & 0,90 & 0,79 & 0,91 & 0,99 & 1,05 & 0,90 & 0,99 & 0,77 \\
\hline
\end{tabular}

Sumber: Analisis, 2011

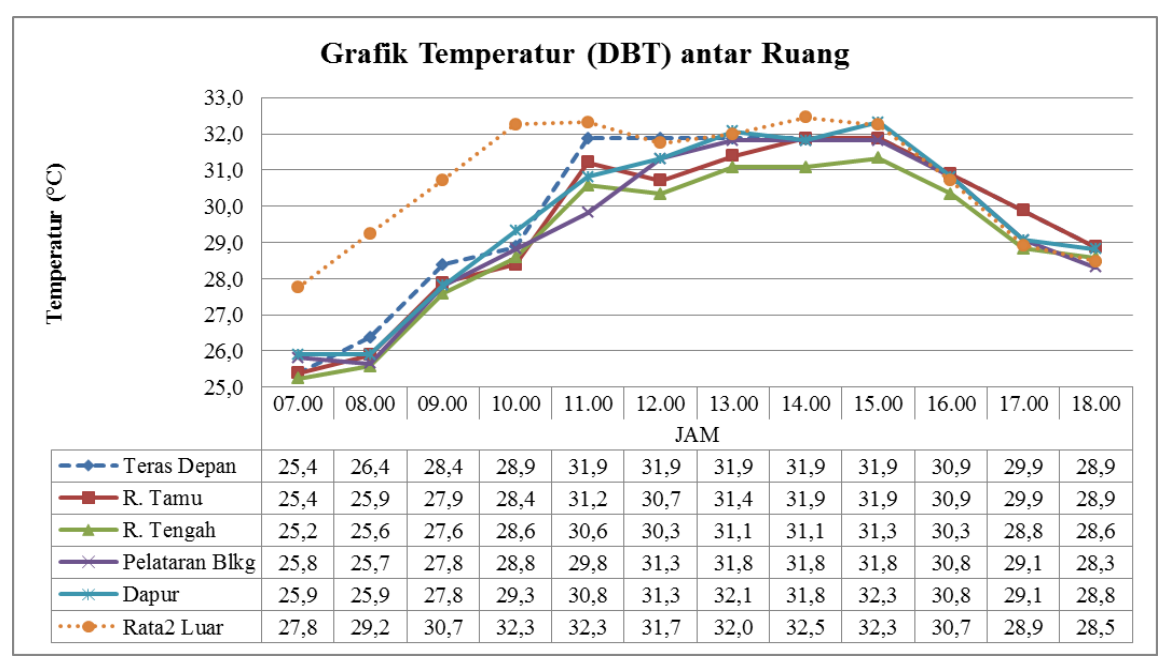

Gambar 21. Grafik perbandingan perubahan temperatur (DBT) antar ruang pada Rumah 2.

Sumber: Analisis, 2011

Kelajuan angin ruang dalam lebih rendah daripada ruang luar $(0,77 \mathrm{~m} / \mathrm{s})$. Pada teras depan kelajuan turun menjadi $0,37 \mathrm{~m} / \mathrm{s}$ dan menjadi lebih rendah yaitu $0,20 \mathrm{~m} / \mathrm{s}$ di ruang tamu. Demikian pula di ruang belakang (dapur), kelajuan angin hanya sebesar 0,30 $\mathrm{m} / \mathrm{s}$. Namun di pelataran belakang dan ruang tengah, kelajuan bertambah sebesar masing-masing $0,35 \mathrm{~m} / \mathrm{s}$ dan $0,33 \mathrm{~m} / \mathrm{s}$. Hal ini menunjukkan terdapat pengaruh hadirnya ruang pelataran belakang dalam pergerakan angin dalam bangunan. 


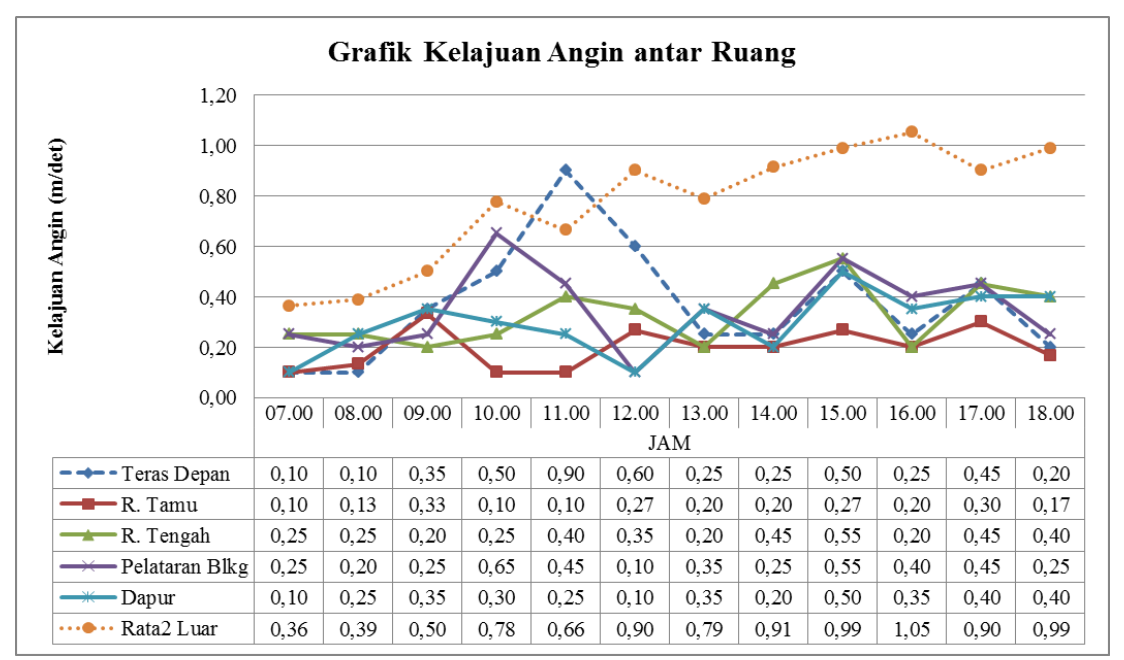

Gambar 22. Grafik perbandingan perubahan kelajuan angin (V) antar ruang pada Rumah 2.

Sumber: Analisis, 2011

Selain pada masing-masing rumah, fenomena kelajuan angin yang terjadi antara dua rumah tersebut juga dibandingkan. Hal ini dilakukan karena terdapat perbedaan tata ruang di antara kedua rumah, yaitu Rumah 1 tidak lagi terdapat pelataran belakang (karena yang dulunya pelataran belakang sudah berubah menjadi teras belakang) dan Rumah 2 masih memiliki pelataran belakang dan rumah anak yang difungsikan sebagai dapur.

Pada Rumah 1 rata-rata kelajuan angin di ruang dalam (ruang tamu dan ruang tengah) adalah $0,3 \mathrm{~m} / \mathrm{s}$ sementara rata-rata kelajuan angin ruang luar adalah $0,98 \mathrm{~m} / \mathrm{s}$. Selisih antara kelajuan angin ruang luar dan ruang dalam adalah $0,68 \mathrm{~m} / \mathrm{s}$. Pada Rumah 2 rata-rata kelajuan angin di ruang dalam (ruang tamu dan ruang tengah) adalah $0,27 \mathrm{~m} / \mathrm{s}$ sementara rata-rata kelajuan angin ruang luar adalah $0,77 \mathrm{~m} / \mathrm{s}$. Selisih antara kelajuan angin ruang luar dan ruang dalam adalah $0,51 \mathrm{~m} / \mathrm{s}$. Ternyata selisih kelajuan angin di Rumah 2 lebih kecil daripada Rumah $1(0,51 \mathrm{~m} / \mathrm{s}$ dibandingkan $0,77 \mathrm{~m} / \mathrm{s})$. Selisih yang lebih kecil ini menunjukkan bahwa kondisi ruang luar lebih banyak berpengaruh terhadap kelajuan angin di ruang dalam Rumah 2 daripada Rumah 1 dan sangat mungkin ini terjadi karena peran ruang pelataran belakang dalam mengatur kelajuan udara di dalam bangunan.

\section{Kesimpulan}

Berdasarkan hasil pengukuran lapangan yang telah dilakukan pada variabel kenyamanan termal, dapat ditarik kesimpulan sebagai berikut:

- Temperatur ruang dalam rumah melayu Pontianak lebih rendah daripada ruang luar, walaupun masih belum termasuk dalam kategori nyaman $\left(<28^{\circ} \mathrm{C}\right)$.

- Ventilasi alami yang terjadi di dalam bangunan cukup baik, kelajuan angin yang terjadi di dalam bangunan dipengaruhi kelajuan angin di ruang luar.

- Teras cukup berperan dalam menurunkan temperatur luar yang masuk ke dalam bangunan. Baik teras depan maupun teras/pelataran belakang menjadi ruang transisi turunnya temperatur luar sebelum masuk ke ruang dalam.

- Pelataran belakang turut berperan dalam mengatur kelajuan udara di dalam bangunan. Bangunan tanpa pelataran belakang memiliki rentang kelajuan angin ruang dalam dan ruang luar yang lebih tinggi (selisih $0,77 \mathrm{~m} / \mathrm{s}$ ) dibanding bangunan dengan pelataran belakang (selisih $0,51 \mathrm{~m} / \mathrm{s}$ ). Sementara yang diinginkan adalah rentang yang lebih kecil, karena menandakan penyesuaian ruang dalam terhadap ruang luar untuk mendapatkan kelajuan angin yang optimal. Hasil penelitian menunjukkan bahwa tata ruang di rumah vernakular melayu Pontianak turut berperan dalam penghawaan alami yang terjadi di ruang dalam. Keberadaan teras dan pelataran belakang memberikan pergerakan udara yang lebih mendekati pergerakan di ruang luar yang lebih 
lancar. Perlu diteliti lebih lanjut tentang efisiensi penggunaan teras dan pelataran belakang dan juga dukungan elemen bangunan yang lain di luar tata ruang dalam pada kinerja penghawaan alami.

Selain itu, penelitian ini juga menunjukkan kehandalan arsitektur vernakular sebagai contoh arsitektur yang beradaptasi dengan lingkungannya dan merupakan arsitektur yang berkesinambungan (sustainable).

\section{Daftar Pustaka}

Boutet, Terry S. (1987) Controlling Air Movement: A Manual for Architects and Builders. New York: McGraw-Hill Book Company.

Caesariadi, Tri Wibowo; Kalsum, Emilya (2011) Climatic Responsive Space in Melayu Pontianak House: A Preliminary Study. The CIB International Conference: Enhancing the Locality in Architecture, Housing and Urban Environment. January 22, 2011. Yogyakarta.

Engin, N.; Vural, N.; Vural, S.; Sumerkan, M.R. (2005) "Climatic Effect in the Formation of Vernacular Houses in the Eastern Black Sea Region". Building and Environment, Vol. 42. www. sciencedirect.com

Gutierrez, Jorge (2004) "Notes On the Seismic Adequacy of Vernacular Buildings". Paper No. 5011. $13^{\text {th }}$ World Conference on Earthquake Engineering. Vancouver.
Koenigsberger, O.H.; Ingersoll, T.G.; Mayhew, Alan; Szokolay, S.V., (1973) Manual of Tropical Housing and Building, Part One: Climatic Design, London: Longman Group Limited.

Lechner, Norbert (2001) Heating, Cooling, Lighting: Design Methods for Architects. New York: John Wiley \& Sons, Inc.

Lippsmeier, Georg (1997) Bangunan Tropis. Jakarta: Erlangga.

Sozen, Mujgan S.; Gedik, Gulay Z. (2006) "Evaluation of Traditional Architecture in Terms of Building Physics : Old Diyarbakir Houses". Build and Environment, Vol. 42. www.elsevier.com.

Szokolay, Steven V. (2008) Introduction to Architectural Science: The Basis of Sustainable Design, $2^{\text {nd }}$ ed.. Oxford: Architectural Press Elsevier. 